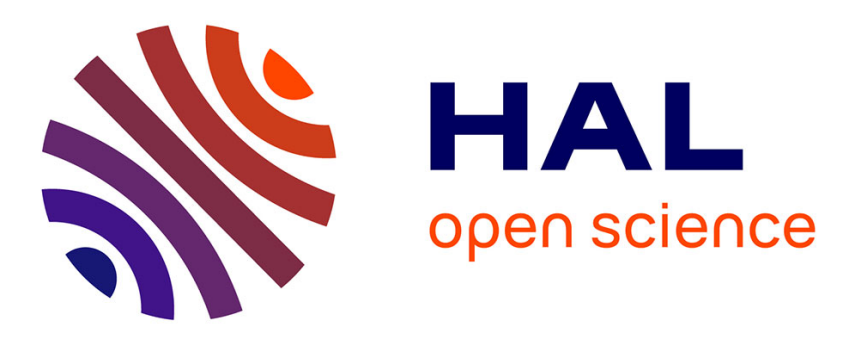

\title{
Novel biological and possible applicable roles of LH/hCG receptor
}

Adam J. Ziecik, Monika M. Kaczmarek, Agnieszka Blitek, Anna E. Kowalczyk, Xiangdong Li, Nafis A. Rahman

\section{- To cite this version:}

Adam J. Ziecik, Monika M. Kaczmarek, Agnieszka Blitek, Anna E. Kowalczyk, Xiangdong Li, et al. Novel biological and possible applicable roles of LH/hCG receptor. Molecular and Cellular Endocrinology, 2007, 269 (1-2), pp.51. 10.1016/j.mce.2006.08.016 . hal-00531899

\section{HAL Id: hal-00531899 \\ https://hal.science/hal-00531899}

Submitted on 4 Nov 2010

HAL is a multi-disciplinary open access archive for the deposit and dissemination of scientific research documents, whether they are published or not. The documents may come from teaching and research institutions in France or abroad, or from public or private research centers.
L'archive ouverte pluridisciplinaire HAL, est destinée au dépôt et à la diffusion de documents scientifiques de niveau recherche, publiés ou non, émanant des établissements d'enseignement et de recherche français ou étrangers, des laboratoires publics ou privés. 


\section{Accepted Manuscript}

Title: Novel biological and possible applicable roles of $\mathrm{LH} / \mathrm{hCG}$ receptor

Authors: Adam J. Ziecik, Monika M. Kaczmarek, Agnieszka Blitek, Anna E. Kowalczyk, Xiangdong Li, Nafis A. Rahman

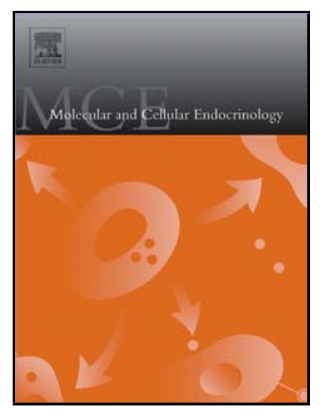

PII:

S0303-7207(07)00047-0

DOI: doi:10.1016/j.mce.2006.08.016

Reference: MCE 6613

To appear in: $\quad$ Molecular and Cellular Endocrinology

Received date: $\quad$ 2-6-2006

Revised date: $\quad 1-8-2006$

Accepted date: $\quad 1-8-2006$

Please cite this article as: Ziecik, A.J., Kaczmarek, M.M., Blitek, A., Kowalczyk, A.E., Li, X., Rahman, N.A., Novel biological and possible applicable roles of LH/hCG receptor, Molecular and Cellular Endocrinology (2007), doi:10.1016/j.mce.2006.08.016

This is a PDF file of an unedited manuscript that has been accepted for publication. As a service to our customers we are providing this early version of the manuscript. The manuscript will undergo copyediting, typesetting, and review of the resulting proof before it is published in its final form. Please note that during the production process errors may be discovered which could affect the content, and all legal disclaimers that apply to the journal pertain. 


\section{Novel biological and possible applicable roles of $\mathrm{LH} / \mathrm{hCG}$ receptor}

Adam J. Ziecik ${ }^{\mathrm{a}, *}$, Monika M. Kaczmarek ${ }^{\mathrm{a}}$, Agnieszka Blitek ${ }^{\mathrm{a}}$, Anna E. Kowalczyk ${ }^{\mathrm{a}}$, Xiangdong $\mathrm{Li}^{\mathrm{b}}$ and Nafis A. Rahman ${ }^{\mathrm{c}}$.

${ }^{a}$ Division of Reproductive Endocrinology and Pathophysiology, Institute of Animal Reproduction and Food Research of Polish Academy of Sciences, Tuwima 10, 10-747 Olsztyn, Poland; ${ }^{\mathrm{b}}$ State Key Laboratory of the Agro-Biotechnology, Faculty of Biological Sciences, China Agricultural University, Beijing 100094, China, ${ }^{\mathrm{c} D e p a r t m e n t}$ of Physiology, University of Turku, Turku, FIN-20520, Finland

* Corresponding author. Tel.: +48 89 5357422; fax: +48 895357421.

E-mail address: ziecik@pan.olsztyn.pl (A.J. Ziecik) 


\begin{abstract}
Luteinizing hormone/human chorionic gonadotropin $(\mathrm{LH} / \mathrm{hCG})$ receptors are widely expressed in gonadal cells, however, the presence of these receptors has also been demonstrated in several other non-gonadal female and male tissues. The expression level of non-gonadal LH/hCG receptors is much lower than in gonads, although their expression is regulated by similar mechanisms and they also exert biological effects using similar signaling pathways. Hormonally regulated $\mathrm{LH} / \mathrm{hCG}$ receptor expression in the oviduct suggests that $\mathrm{LH}$ could be involved in the regulation of its contraction, gametes/embryos transport and synchronization of the fertilization. One of the major roles of the myometrial $\mathrm{LH} / \mathrm{hCG}$ receptors may also be the stimulation of growth and maintenance of the uterine relaxation during pregnancy. In pigs, LH seems to be one of the pleiotropic factors which influence the endometrial prostaglandin $\mathrm{F}_{2 \alpha}$ synthesis and initiation of the luteolysis. The $\mathrm{LH} / \mathrm{hCG}$ receptor expression in several cancer cells provides new possibilities for developing new strategies for targeted cancer therapy based on lytic LH/hCG conjugates.
\end{abstract}

Key words: LH/hCG receptor; uterus; oviduct; cancer 


\section{Introduction}

Approximately 30 years ago the luteinizing hormone/human chorionic gonadotropin $(\mathrm{LH} / \mathrm{hCG})$ receptor was demonstrated to be an integral component of the granulose, and luteal cells in the ovary and the Leydig cells of testes. In the available literature, the first report on non-gonadal LH/hCG binding sites was described in the porcine uterus (Ziecik et al., 1986). However, the first unintentional discovery of $\mathrm{LH} / \mathrm{hCG}$ receptors out of gonads was made by Hannu Rajaniemi in his doctoral dissertation ${ }^{1}$. In this one autoradiogram clearly shows binding of ${ }^{125}$ I-labeled LH not only in the ovaries but also in the uterus (unpublished data/ $\mathrm{PhD}$ thesis/University of Turku, Turku Finland/personal communication). The presence of $\mathrm{LH} / \mathrm{hCG}$ receptors in the uterus was next demonstrated in rabbit (Sawitzke and Odell, 1991; Jensen and Odell, 1988), rat (Sawitzke and Odell, 1991; Bonnamy et al., 1990), mouse (Ziecik et al., 1992a; Mukherjee et al., 1994) and human (Reshef et al., 1990). Although nongonadal $\mathrm{LH} / \mathrm{hCG}$ receptors have been described in many species, the most numerous investigations were performed in humans and pigs. To date it is clear, that $\mathrm{LH} / \mathrm{hCG}$ receptors are widely distributed in non-gonadal tissues including the female and male reproductive tract (oviduct, uterus and male accessory sex organs), placenta, mammary gland, brain, adrenal cortex, T lymphocytes and urinary bladder (Table 1; for a review see Rao, 1996). Recently, the association of neuronal $\mathrm{LH} / \mathrm{hCG}$ receptor expression with sensory, memory, reproductive behavior and autonomic structures has also been identified (Apaja et al., 2004).

The pig is a species distant in phylogeny from humans, but unexpectedly, the transgenic pig became the most convenient animal donor for xenotransplantation of many organs for humans (Polejaeva et al., 2000). In this article we describe the distribution of $\mathrm{LH} / \mathrm{hCG}$ receptors expression in the female reproductive tract and their involvement in the porcine oviduct and uterine function and compare these functions to human and other

\footnotetext{
${ }^{1}$ Rajaniemi, H. 1971. Distribution of pituitary gonadotrophic hormones in experimental animal and binding to target tissues. University of Turku, Turku, Finland.
} 
mammals. Moreover, we discuss new approaches to the development of novel therapies of LH/CG receptor expressing cancers.

\section{Structure and regulation of expression}

The $\mathrm{LH} / \mathrm{hCG}$ receptor gene structure has been defined in the pig, human, rat and mouse (Loosfelt et al., 1989; Tsai-Morris et al., 1991; Huhtaniemi et al., 1992; Atger et al., 1995). In various species, this gene contains 11 exons, separated by 10 introns. Exons 1-10 encode the 5'-untranslated region and most of the extracellular domain. The last exon encodes seven characteristic membrane segments and the intracellular domain containing the Cterminal tail. The predicted mass of the porcine $\mathrm{LH} / \mathrm{hCG}$ receptor polypeptide core is $75 \mathrm{kDa}$. For example, the glycosylated mature receptor expressed in the testes is $85 \mathrm{kDa}$, but less abundant smaller isoforms are also observed (Loosfelt et al., 1989). Transfection of mammalian cells with the cDNA for the rat or the human $\mathrm{LH} / \mathrm{hCG}$ receptor bring about three distinct receptor forms with molecular masses of 75-85 kDa, 85-95 kDa, and 165-200 kDa. The $85-95 \mathrm{kDa}$ band corresponds to the mature $\mathrm{LH} / \mathrm{hCG}$ receptor present at the cell surface. In the pig $\mathrm{LH} / \mathrm{hCG}$ receptor, two minimal critical sequences in the extracellular domain, fragments 21-24 and 102-107, are involved in hormone binding, and the receptor activation centre was localised within the sequence 111-121 (Davis et al., 1995). Two segments of the receptor that participate in hormone-receptor interaction are located in the inner surface of the horseshoe and vicinal loops but not on the $\alpha$-helical stretches forming the outer circumference.

The primary transcriptional start sites of the $\mathrm{LH} / \mathrm{hCG}$ receptor gene both in humans and rats lie within $180 \mathrm{bp} 5^{\prime}$ to the translational ATG codon, and deletion analysis has localized the promoter within this region (Tsai-Morris et al., 1993, 1995; Geng et al., 1999). In rat cell lines, expression of the $\mathrm{LH} / \mathrm{hCG}$ receptor gene is constitutively inhibited by 
upstream sequences -180 to -2678 bp (Tsai-Morris et al., 1993, 1995), whereas in human cell lines, only small inhibitory effects were observed (Geng et al., 1999). This region contains seven activator protein-1 (AP1) binding sites as well as a hemipalindromic cyclic adenosine monophosphate (cAMP) response element (hCRE) domain, which have the potential to bind the Jun/Fos and cAMP response element-binding protein (CREB)/modulator protein (CREM)/activating transcription factor (ATF) bZIP transcription factor families, respectively. The human and rat $\mathrm{LH} / \mathrm{hCG}$ receptor gene is TATA-less and contains EREhs direct repeats and two specificity proteins (Sp) 1-4 CG binding domains (I and II) within the proximal promoter (Phillips et al., 2005).

The distal -180 to -2678 bp region of the promoter, although capable of binding members of the Jun family via the multiple AP1 binding domains within this region, has no major role in regulating expression of the $\mathrm{LH} / \mathrm{hCG}$ receptor gene in myometrial cells (Phillips et al., 2005). In contrast, the two Sp1-4 CG boxes within the +1 to -180 bp proximal promoter are central to expression of the gene in the myometrium (Geng et al., 1999), as reported in other human cell lines (Zhang and Dufau, 2003). However, not only Sp1/Sp3 proteins are involved in this process in the myometrium, but Sp4 and a novel Sp-like factor(s) also take part in transcriptional regulation of this gene. It would appear that $\mathrm{Sp} 1 / \mathrm{Sp} 3 / \mathrm{Sp} 4$ and $\mathrm{Sp}$-like proteins are all involved in recruiting histone deacetylase (HDAC) complexes to the promoter, preventing chromatin remodeling and transcriptional activation (Phillips et al., 2005).

\section{Fallopian tube}

LH/hCG receptor mRNA expression has been shown in human (Lei et al., 1993c) and porcine (Derecka et al., 1995) fallopian tubes. Further immunohistochemical experiments revealed that $\mathrm{LH} / \mathrm{hCG}$ receptor protein expression locate in the epithelium of tubal mucosa, smooth muscle cells, and the blood vessel endothelium in pigs (Gawronska et al., 1999). However, in 
the mouse, $\mathrm{LH} / \mathrm{hCG}$ receptors were detected in the serosa and subepithelial cells, but not in the epithelium of the oviduct (Zheng et al., 2001). This discrepancy may reflect the species differences or results from different experimental techniques.

The hormonal status of the pig may also influence the receptor expression levels in the porcine oviduct (Gawronska et al., 1999). Injection of estradiol benzoate was able to upregulate the expression of LH/hCG binding sites in the oviduct (Gawronska et al., 1999). The direct action of estradiol on the $\mathrm{LH} / \mathrm{hCG}$ receptor status was also shown in humans, where estradiol caused up-regulation of these receptors in cultured oviductal epithelial cells (Han et al., 1996). An abundant concentration of $\mathrm{LH} / \mathrm{hCG}$ receptor protein was observed in oviducts obtained from estradiol- and progesterone-treated gilts. Additionally, western blotting analysis revealed the presence of 75,48 and $45 \mathrm{kDa}$ immunoreactive receptor proteins in the porcine oviduct, analogously to the porcine corpus luteum (CL; Gawronska et al., 1999, 2000).

A hormonal profile dependent differential distribution of $\mathrm{LH} / \mathrm{hCG}$ receptors in various oviductal cells, may imply the possibility of a direct involvement of LH in the regulation of the function of fallopian tube. It has been shown that spontaneous contractions of the porcine oviduct could be modulated by LH during various stages of the estrous cycle (Table 2; Gawronska et al., 1999). In vitro experiments showed that LH can modulate the oviduct contractility in gilts primed with both estradiol and progesterone but not in gilts primed only with progesterone, estradiol, or corn oil (Gawronska et al., 1999, 2000). The mechanism underlying the effects of $\mathrm{LH}$ on the oviduct is not clear yet, however, it is possible that its action is based on direct stimulation of local factors, such as prostaglandins (PGs) or nitric oxide (NO). Results of Han et al. (1996) support this concept, since hCG treatment increased cyclooxygenase-2 (COX-2; the key-enzyme in PGs synthesis) mRNA and protein levels and $\mathrm{PGE}_{2}$ production in human oviductal mucosa cells in vitro. It seems that the preovulatory 
surge of LH, beside its major action on the follicle rupture and luteinization of granulosa and theca cells, plays also an important role in the control of oviduct contraction. LH might also be a major factor responsible for opening the ampulla-isthmic junction for spermatozoa and synchronization of fertilization in the ampulla. Moreover, the known relaxing action of LH may facilitate the transport of embryos through the isthmus toward the uterus. Further studies are required to substantiate the hypotheses of LH roles in the fallopian tube.

\section{Myometrium}

$\mathrm{LH} / \mathrm{hCG}$ receptor in myometrium was first identified in pigs (Ziecik et al., 1986), later its expression was confirmed in rabbit (Jensen and Odell, 1988) and in human (Reshef et al., 1990). The expression of $\mathrm{LH} / \mathrm{hCG}$ receptors in the myometrium is higher in the progesteronedominated phase of the estrous cycle than in the estrogen-dominated phase. The receptors are also expressed in the myometrium during pregnancy in humans and pigs and in the postpartum and postmenopausal periods in women (Ziecik et al., 1986; Reshef et al., 1990; Zuo et al., 1994). Cyclic expression patterns of $\mathrm{LH} / \mathrm{hCG}$ receptors in the human menstrual and porcine estrous cycles, along with the known effects of estradiol and progesterone on myometrial LH/hCG receptor expression in ovariectomized pigs (Ziecik et al., 1992b) may suggest that estradiol directly upregulates and progesterone acts through estradiol-primed tissue to increase $\mathrm{LH} / \mathrm{hCG}$ receptor levels in the myometrium as well as in the endometrium (Stepien et al., 1999) and fallopian tubes (Gawronska et al., 2000). The presence of LH/hCG receptors in the myometrium raises an intriguing possibility that $\mathrm{LH} / \mathrm{hCG}$ may also have a direct effect on uterine function in addition to its indirect action via ovarian steroid hormones. There are data suggesting that $\mathrm{LH} / \mathrm{hCG}$ receptors may play a role in the hyperplasia and hypotrophy of the uterus (Kornyei et al., 1993) and in the uterine motility having an inhibitory 
effect on the frequency and amplitude of spontaneous myometrial contractions in the porcine uterus (Fig. 1; Flowers et al., 1991).

Myometrial LH/hCG receptors in women are down-regulated following the onset of labor in both term and preterm deliveries (Zuo et al., 1994) suggesting that hCG may have a role in maintaining uterine quiescence during pregnancy. Slattery et al. (2001) clearly demonstrated that hCG exerts a significant concentration-dependent relaxant effect on human myometrial tissue obtained in late pregnancy. This inhibitory effect was not estrogendependent as occurred in other tissue types. These findings clearly demonstrate that hCG has a relaxing effect on the myometrium and thus its clinical utility in the treatment of preterm labor should be estimated. Preliminary treatments, which involved administration of $\mathrm{LH} / \mathrm{hCG}$ or placebo to women in preterm labor, showed significant improvement in terms of pregnancy prolongation and smaller numbers of infants with birth weights less than $2500 \mathrm{~g}$ in the treatment group ${ }^{2}$.

In the porcine myometrial cells, hCG activates two different signaling systems, adenylate cyclase and phospholipase C (Kisielewska et al., 1996). The exact mechanism of the inhibitory effect of hCG is unknown but direct reduction of intracellular calcium availability (Eta et al., 1994), down regulation of myometrial gap junction (Ambrus and Rao, 1994) and changes in the synthesis of eicosanoids (Zuo et al., 1994) are very likely to be involved in this mechanism. The action of hCG on myometrium is primarily mediated via coupling of $\mathrm{LH} / \mathrm{hCG}$ receptors to the adenyl stimulatory $\mathrm{G}$ protein, $\mathrm{G} \alpha_{\mathrm{s}}$, and the formation of cAMP. Increased accumulation of cAMP in the myometrium during pregnancy as a result of stimulation of the adenyl cyclase pathway by hCG may also be potentiated by the increase in levels of $\mathrm{G}_{\mathrm{s}^{-}}$and $\mathrm{G} \alpha_{\mathrm{s}}$-coupled adenyl cyclase activities (Europe-Finner et al., 1993). The molecular processes by which expression of the $\mathrm{G} \alpha_{\mathrm{s}}$ gene may be regulated in human

\footnotetext{
${ }^{2}$ Ali, F.M., Fateen, B., Ezzet, A., Badawy, H., Ramadan, A., El-tobge A., 2000. Treatment of preterm labor with human chorionic gonadotropin: a new modality. Obstet. Gynecol. 95, 104.
} 
myometrium during pregnancy appears to involve binding of Sp-like transcription factors to GC boxes within the promoter region of the gene that stimulates expression of the $\mathrm{G} \alpha_{\mathrm{s}}$ gene via a protein kinase A (PKA)-dependent mechanism (Phillips et al., 2002). Recently, Phillips et al. (2005) showed that Sp1/Sp3/Sp4 and Sp-like proteins are involved in recruiting HDAC complexes to the proximal promoter in the human myometrium, preventing chromatin remodeling and resulting in transcriptional regression of the gene. These data suggest that administration of the HDAC inhibitor, trichostatin A, to the human myometrial cells in vitro and in vivo substantially removes this silencing effect on expression of the gene. Therefore, the use of this and similar agents could be considered to upregulate myometrial $\mathrm{LH} / \mathrm{hCG}$ receptor levels and subsequent maintenance of the uterine relaxation during fetal maturation.

\section{Endometrium}

First observations of endometrial LH/hCG binding sites were made in the pig (Ziecik et al., 1986). The $\mathrm{LH} / \mathrm{hCG}$ receptors were also characterized in the bovine endometrium (Freidman et al., 1995). The highest concentration of these receptors in the bovine endometrial tissue was observed on days 15 to 17 of the estrous cycle and decline afterwards to a nadir. In human endometrium, expression of gonadotropin receptors was also demonstrated in the proliferative and secretory phases of the menstrual cycle, the $\mathrm{LH} / \mathrm{hCG}$ receptors immunoreactivity in cells from the secretory phase being higher than in corresponding cells from the proliferative phase of the cycle (Reshef et al., 1990). In pigs, endometrial $\mathrm{LH} / \mathrm{hCG}$ receptor expression was investigated at the protein and mRNA levels. Western blot analysis revealed the presence of the predominant $75 \mathrm{kDa}$ immunoreactive species in crude membrane preparations of the porcine endometrium, analogously to the $\mathrm{CL}$ (Stepien et al., 1999). A higher concentration of this protein was observed on days 10 and 15 of the estrous cycle than on days 5 and 19. Expression of $\mathrm{LH} / \mathrm{hCG}$ receptors in the 
endometrium and endometrial blood vessels of the pig was also demonstrated using autoradiography with ${ }^{125}$ I-labeled hCG (Wasowicz and Ziecik, 2000).

A higher level of endometrial $\mathrm{LH} / \mathrm{hCG}$ receptors before and at the time of luteolysis in pigs and cows suggested the possible role of LH in PGs synthesis (Fig. 2). Indeed, LH induces $\mathrm{COX}$ protein expression and increases $\mathrm{PGF}_{2 \alpha}$ release from bovine endometrium (Shemesh et al., 1994). In both species, pulsatile release of $\mathrm{PGF}_{2 \alpha}$ from the endometrium is responsible for initiation of luteolysis, but the stimulus for its secretion has not been well elucidated (Ziecik et al., 2001). We showed that in pigs $\mathrm{LH}$ is able to stimulate $\mathrm{PGF}_{2 \alpha}$ secretion from endometrial tissue (Stepien et al., 1999) as well as separately cultured stromal and luminal epithelial cells (Fig. 3; Blitek and Ziecik, 2005). Incubation of endometrial explants with LH resulted in an increase of $\mathrm{PGF}_{2 \alpha}$ output in a dose-dependent manner on days 5-16 of the estrous cycle. However, the strongest effect was found during luteolysis (days 1416) of the estrous cycle. Moreover, a LH-stimulated upregulation of COX protein has also been shown (Stepien et al., 1999).

LH is released in a pulsatile manner during the luteal phase of the estrous cycle (Parvizi et al., 1976; Van de Wiel et al., 1981). Since both systemic infusion (Ziecik et al., 2001) and intramuscular injection of hCG (Guthrie and Bolt, 1983) were reported to be able to induce $\mathrm{PGF}_{2 \alpha}$ release in vivo, we thus hypothesized that the endogenous LH pulses may provoke PGs secretion from the porcine endometrium. This hypothesis has been supported by the observations that much higher correlation exists between LH and 13,14-dihydro-15-keto $\mathrm{PGF}_{2 \alpha}$ (PGFM) peaks (79.2\%, Ziecik et al., 2001) than between oxytocin and PGFM (30\%, Kotwica et al., 1999). At the time of luteolysis, the number of endometrial LH/hCG receptors reaches the maximum in pigs. However, after initiation of luteolytic secretion of $\mathrm{PGF}_{2 \alpha}$ on days 14-16 of the estrus cycle, concentration of endometrial $\mathrm{LH} / \mathrm{hCG}$ receptors starts to decline (Stepien et al., 1999). Interestingly, during the same period of the estrous cycle, the 
number of $\mathrm{LH} / \mathrm{hCG}$ receptors in the porcine CL also declines (Fig. 2; Ziecik et al., 1980). Other results showed that injection of hCG during the late luteal phase of the estrous cycle increased concentrations of peripheral PGFM in cows (Fields and Shemesh, 2004).

The "luteolytic" action of LH is restricted only to the late luteal phase of the porcine estrous cycle. After fertilization, the developing blastocyst is able to overcome this effect and restores the classical luteotropic action of LH. Estrogen produced by blastocyst seems to act as an anti-luteolysin and causes a redirection of endometrial $\mathrm{PGF}_{2 \alpha}$ secretion from the uterine vasculature (endocrine) into the uterine lumen (exocrine) (Bazer and Thatcher, 1977; Krzymowski and Stefanczyk-Krzymowska, 2002). Additionally, the presence of blastocysts in the uterine lumen probably alters the release of the final product of PG synthesis in the pig. It appears to happen by induction of $\mathrm{PGE}_{2}$ secretion instead of $\mathrm{PGF}_{2 \alpha}$ (Moeljono et al., 1977; Akinlosotu et al., 1988) or at least by changing the $\mathrm{PGE}_{2}: \mathrm{PGF}_{2 \alpha}$ ratio to favor luteotropic $\mathrm{PGE}_{2}$ effects (Davis and Blair, 1993; Ziecik et al., 2001). Our recent unpublished data suggest that up-regulation of PGE synthase in conceptus on days 10-12 of pregnancy may be important in modulating ratio for the maternal recognition and establishment of pregnancy in pigs $^{3}$. Moreover, the luteolytic effect of $\mathrm{PGF}_{2 \alpha}$ on luteal cells collected from mature and regressing porcine $\mathrm{CL}$ can be abolished by the increase of the $\mathrm{PGE}_{2}: \mathrm{PGF}_{2 \alpha}$ ratio in vitro (Gregoraszczuk and Michas, 1999). Recently, we have also found that exogenous estrogen administration between days 11 and 15 after the onset of estrus results in elevation of LHinduced $\mathrm{PGE}_{2}$ release from cultured porcine endometrium $(\mathrm{G}$. Bodek and A.J. Ziecik unpublished data). This data is in agreement with earlier published data of Christenson et al. (1994) on PGs output in non-mated and mated gilts. In contrast to non-mated gilts, PG secretion in mated gilts reached a peak earlier with a domination of $\mathrm{PGE}_{2}$ synthesis. Garverick et al. (1982) suggested that estrogen of conceptus origin is an additional stimulus for the

\footnotetext{
${ }^{3}$ Waclawik, A., Blitek, A., Kaczmarek, M., Ziecik, A.J., 2005. Expression patterns of mPGES-1 and PGFS in pig trophoblast. The $4^{\text {th }}$ Joint Meeting of the UK Fertility Societies, Warwick, UK, 3-6 April.
} 
maintenance of $\mathrm{LH} / \mathrm{hCG}$ receptors in the $\mathrm{CL}$ by a mechanism that is independent of the porcine uterus.

It is very likely that LH mediates its actions upon the porcine endometrial cells via two intracellular second messenger systems (Stepien and Ziecik, 2002). The first one involves the activation of adenylate cyclase and production of cAMP and the second one the stimulation of phosphoinositide-specific phospholipase $\mathrm{C}$ and the activation of protein kinase $\mathrm{C}$. The same signaling pathways mediate LH action in the ovary (Marsh, 1975; Davis et al., 1987) and myometrium of pigs (Kisielewska et al., 1996) as well as in the bovine cervical tissues (Mizrachi and Shemesh, 1999). Taken together, it appears that LH/hCG action on porcine endometrium induces $\mathrm{PGF}_{2 \alpha}$ production which contributes to the regression of the CL (Fig 2). $\mathrm{LH}$ binding to the endometrial receptors in pigs and cows and $\mathrm{LH}$ induced secretion of $\mathrm{PGE}_{2}$ in the placentoma of the ewe suggest that $\mathrm{LH} / \mathrm{hCG}$ together with other embryonic factors could be applied for development of new strategies for improvement of reproductive efficiency in domestic animals (Weems et al., 2003).

\section{Uterine blood flow}

$\mathrm{LH} / \mathrm{hCG}$ receptors are expressed in the vascular smooth muscle layer of arteries and veins of the porcine broad ligament (Ziecik et al., 1995). Small vessels supplying and draining blood from the uterus, except the uterine artery, show higher concentrations of $\mathrm{LH} / \mathrm{hCG}$ receptors during the luteal than the follicular phase of the estrous cycle. Uterine veins, but not arteries, of proestrus/estrus cows express LH/hCG receptors (Shemesh et al., 1997). Presence of $\mathrm{LH} / \mathrm{hCG}$ receptors in the uterine vascular system may be necessary for LH-induced COX-2 expression and increased PGs synthesis in the uterine veins (Shemesh et al., 1997). Therefore, the maximal stimulation of the $\mathrm{LH} / \mathrm{hCG}$ receptor during proestrus/estrus stage may serve to increase the amounts of prostanoids reaching the regressing CL. It happens either directly by 
increasing prostanoid production in the vascular bed or indirectly by increasing the blood flow to the ovary.

Administration of hCG to gilts in the luteal phase and also to estrogen and progesterone primed ovariectomized gilts shows that $\mathrm{LH} / \mathrm{hCG}$ may directly influence the blood flow (Ziecik et al., 1996). The uterine blood flow response was biphasic after hCG treatment. The first early phase occurred about 1 hour after hCG injection and the second later phase about 1 hour after the onset of the peak of estradiol release. It has been known for some time that both single injection and infusion of hCG into gilts in the luteal phase of the estrous cycle can significantly elevate estradiol-17 $\beta$ concentrations in systemic blood 3 hours later (Ziecik et al., 1996). Therefore, the first phase of the uterine blood flow response in gilts could directly be induced by hCG, but the second is more likely an estradiol effect. It has been shown that estrogen induces uterine vasodilatation in the pig (Ford, 1985), sheep (Van Buren et al., 1992) and women (Kurjak et al., 1991). Toth et al. (1994) suggested that hCG could regulate formation of vasoactive eicosanoids via the COX pathway of arachidonic acid metabolism in uterine arteries. According the above authors the vasodilatory effect could be due to the hCG-induced increase of $\mathrm{PGI}_{2}$ and consequent decrease of thromboxane $\mathrm{A}_{2}$ synthesis.

The precise mechanism involved in vasoactive action of $\mathrm{LH} / \mathrm{hCG}$ is not yet known. Recently, it has been demonstrated that LH caused a significant attenuation of vascular response to norepinephrine (NE) in the third order branches of porcine uterine artery ${ }^{4}$ whereas NE induced a dose-dependent contraction of all experimental and control arteries, addition of LH caused a sidewards shift of the dose-response curve to NE. The corresponding $\mathrm{EC}_{50}$ values $(\mu \mathrm{mol} / \mathrm{l})$ were $2.2 \pm 04$ in phosphate buffered saline (PBS) and $3.3 \pm 0.4(\mathrm{p}<0.05)$ in LH pre-treated vessels. Also intraperitoneal administration of hCG caused attenuation of the

\footnotetext{
${ }^{4}$ Skipor, J., Kowalik, A., 2005. Luteinizing hormone attenuates the vascular response to norepinephrine. The $4^{\text {th }}$ Symposium of the Society for Biology of reproduction, Cracow, Poland, 22-24 September.
} 
contractile responses of isolated rat aortic rings to phenylephrine, angiotensin $\mathrm{II}, \mathrm{CaCl}_{2}$ and $\mathrm{KCl}$ (Ezimokhai et al., 2000). This effect of hCG could be contributed to the attenuated vascular responses in normal pregnancy.

\section{Targeted treatment of the gonadal and non-gonadal tumors through LH/hCG receptors}

Presently available cancer treatments are mostly based on chemotherapeutic drugs cytotoxic not only to rapidly dividing tumor cells but also to normal cells. The major problem of cancer chemotherapy is that it has severe side effects (Boman, 1995) and the search for an effective, non-toxic to normal cells dose is still difficult. Therefore, one focus of the ongoing research in this field is to evaluate more selective ways to delivery chemotherapeutic agents to the primary tumor and their metastases, which allow the use of higher doses without side effects to normal cells (Magrath, 1994). Since specific binding sites for LH/hCG receptor are present in breast (Lojun et al., 1997; Meduri et al., 1997), uterine (Lei et al., 1993b; Lin et al., 1994; Singh et al., 1995), ovarian and prostate cancers (Emons et al., 1992; Tao et al., 1997; Dirnhofer et al., 1998), targeted treatment of these tumors based on cytototoxic or lytic LH/hCG conjugates could provide a more specific and efficacious tool for ablation of these malignancies than conventional chemotherapeutics.

Recently, a new approach based on the selectivity of certain carrier molecules for specific binding sites in tumor tissues has been proposed (Leuschner et al., 2001; Hansel et al., 2001). Several synthetic, alpha-helical, membrane disrupting peptides have been linked with a 15-amino acid fragment (81-95) of $\beta$ chain of hCG (Leuschner and Hansel, 2005). The 81- to 95-amino acid region of hCG $\beta$ was selected as ligand, since it is the most potent region of the full size hCG involved in the interaction between hormone and receptor (Morbeck, 1993). The ability of selective destruction of Hecate-CG $\beta$, Phor14-CG $\beta$ and Phor21-CG $\beta$ conjugates has been tested in numerous in vitro and in vivo experiments (Hansel et al. 2001; 
Leuschner et al. 2001, 2003; Gawronska et al., 2002; Bodek et al., 2003, 2005a, b; Zaleska et al., 2003, 2004).

We have investigated in vitro the susceptibility of various gonadal and non-gonadal cancer cell types, expressing and non-expressing $\mathrm{LH} / \mathrm{hCG}$ receptors, to Hecate-CG $\beta$ conjugate treatment (Zaleska et al., 2003; Bodek et al, 2003, 2005a). In a dose- and timedependent manner, the conjugate selectively destroyed cells possessing $\mathrm{LH} / \mathrm{hCG}$ in lower concentrations than Hecate alone and the efficacy strongly correlate with the number of $\mathrm{LH} / \mathrm{hCG}$ receptors. In $\mathrm{LH} / \mathrm{hCG}$ receptor non-expressing cells, Hecate-CG $\beta$ conjugate was effective only in high concentrations, similar to Hecate alone (Bodek et al, 2005a).

Administration of Hecate-CG $\beta$ conjugate has efficiently inhibited the growth of diethylstilbestrol/dimethylbenz[a]anthracene (DES/DMBA)-induced rat mammary tumors in vivo, although we were able to document the expression of $\mathrm{LH} / \mathrm{hCG}$ in tumors in only $17 \%$ of the treated rats (Zaleska et al., 2004). Interestingly, the treatment did not affect estradiol, LH, follicle-stimulating hormone (FSH) and thyroid-stimulating hormone (TSH) blood plasma concentrations. However, our recent results have revealed a significant decrease of prolactin (PRL) and growth hormone (GH) levels in the blood plasma of Hecate-CG $\beta$ conjugate treated animals (our unpublished results), which may indicate an unknown systemic effect of HecateCG $\beta$ conjugate treatment. To date it is not clear how Hecate-CG $\beta$ conjugate effectively reduces the volume of DES/DMBA-induced rat mammary tumors, further studies are required to elucidate the in vivo mechanisms of action of the conjugate in mammary gland tumors in rats.

Increasing concentrations of Hecate-CG $\beta$ conjugate have been shown to inhibit binding of hCG to the receptors. Thus, it seems that binding abilities of used fragment of hCG $\beta$ were not influenced by the conjugation process (Bodek et al., 2003). Interestingly, the lytic activity of Hecate-CG $\beta$ conjugate can be limited by the hCG. Short-term in vitro 
preincubation of human prostate cancer cells (PC-3) with $100 \mathrm{ng} / \mathrm{ml}$ of gonadotropin led to saturation of $\mathrm{LH} / \mathrm{hCG}$ receptors and protected these cells against the toxicity of Hecate-CG $\beta$ conjugate (Bodek et al., 2005a).

Taken together, several in vitro and in vivo experiments proved the concept that Hecate-CG $\beta$ conjugate can be effective in targeted destruction of cells expressing $\mathrm{LH} / \mathrm{hCG}$ receptors. This unique combination of toxic moiety (Hecate) and fragment of $\beta$ chain of hCG may be used in a development of potential targeted therapy of gonadal and non-gonadal tumors expressing $\mathrm{LH} / \mathrm{hCG}$ receptors without causing side effects. However, further studies are needed in order to determine the detailed mechanism of Hecate-CG $\beta$ conjugate action and regulation of conjugate cell/receptor specific destruction, as well as the minimal effective dose and the best method of administration. 
Table 1. Evidence of LH/hCG receptor in non-gonadal tissues of human and pig

\begin{tabular}{|c|c|c|}
\hline Tissue & Human & Pig \\
\hline Myometrium & (+) Reshef et al., 1990 & (+) Ziecik et al., 1986 \\
\hline Endometrium & (+) Reshef et al., 1990 & (+) Ziecik et al., 1986 \\
\hline Oviduct & (+) Lei et al., 1993c & $(+)$ Gawronska et al., 1999 \\
\hline Broad ligamnet & (?) & (+) Ziecik et al. 1995 \\
\hline Uterine vessels & (+) Toth et al., 1994 & (+) Wasowicz and Ziecik, 2000 \\
\hline Cervix & (+) Lin et al., 2003 & (+) Stepien et al., 2000 \\
\hline Mammary gland & (+) Lojun et al., 1997 & (+) Meduri et al, 1997 \\
\hline Placenta & (+) Reshef et al., 1990 & (?) \\
\hline Umbilical cord & (+) Rao et al., 1993 & (+) Wasowicz et al., 1999 \\
\hline Brain & (+) Lei et al., 1993a & (?) \\
\hline Adrenals & (+) Pabon et al., 1996b & (?) \\
\hline Skin & (+) Pabon et al., 1996a & (?) \\
\hline Lymphocytes & (+) Lin et al., 1995 & (?) \\
\hline Epididymis & (+) Rao, 2001 & (+) A.J. Ziecik, unpublished data \\
\hline Prostate & (+) Dirnhofer et al., 1998 & (?) \\
\hline
\end{tabular}

(+) - evidence of LH/hCG receptor presence; (?) - lack of data 
Table 2. Mean ( \pm SEM) frequency and amplitude of spontaneous contraction of the pig isthmus collected during different stages of the estrous cycle and incubated with LH (100 ng/ml) (modified from Gawronska et al., 1999).

\begin{tabular}{|lcccc|}
\hline \multirow{2}{*}{$\begin{array}{l}\text { Stage of the } \\
\text { estrous cycle }\end{array}$} & \multicolumn{2}{c}{ Frequency } & \multicolumn{2}{c|}{ Amplitude } \\
\cline { 2 - 5 } & II & III & II & III \\
\hline $\begin{array}{l}\text { Days 18-2 } \\
\text { (peri-ovulatory) }\end{array}$ & $101.1 \pm 9.3$ & $77.4 \pm 7.8$ & $83.4 \pm 8.6$ & $68.4 \pm 7.3^{*}$ \\
$\begin{array}{l}\text { Days 5-8 } \\
\text { (early luteal) }\end{array}$ & $94.5 \pm 5.9$ & $98.7 \pm 0.7$ & $105.8 \pm 4.0$ & $79.2 \pm 3.8^{*}$ \\
$\begin{array}{l}\text { Days 13-15 } \\
\text { (late luteal) }\end{array}$ & $104.3 \pm 6.9$ & $82.3 \pm 11.8$ & $93.1 \pm 6.9$ & $59.4 \pm 15.1^{*}$ \\
$\begin{array}{l}\text { Days 16-17 } \\
\text { (early follicular) }\end{array}$ & $94.9 \pm 3.1$ & $99.5 \pm 4.21$ & $112.7 \pm 11.9$ & $112.8 \pm 15.7$ \\
\hline
\end{tabular}

The responses are expressed as percentage of initial values (period I: from 10 to 0 min before hormone treatment; period II: from 0 to $10 \mathrm{~min}$; and period III: from 20 to $30 \mathrm{~min}$ after LH addition). ${ }^{*} \mathrm{P}<0.05$ versus period $\mathrm{I}$ in rows. 


\section{Acknowledgments}

This work was supported by grants from the Committee of Scientific Research in Poland

(Grant No.: 5 P06D 047 14; 5 P06K 034 16; 5 P06K 009 17) and by Domestic Grant for Young Scientists from the Foundation for Polish Sciences awarded to M.M. Kaczmarek. 


\section{References}

Akinlosotu, B.A., Diehl, J.R., Gimenez, T., 1988. Prostaglandin E2 counteracts the effect of PGF2 $\alpha$ in indomethacin treated gilts. Prostaglandins 35, 81-93.

Ambrus, G., Rao, C.V., 1994. Novel regulation of pregnant human myometrial smooth muscle cell gap junctions by human chorionic gonadotropin. Endocrinology 135, 2772-2779. Apaja, P.M., Harju, K.T., Aatsinki, J.T., Petaja-Repo, U.E., Rajaniemi, H.J., 2004. Identification and structural characterization of the neuronal luteinizing hormone receptor associated with sensory systems. J. Biol. Chem. 279, 1899-1906.

Atger, M., Misrahi, M., Sar, S., Le Flem, L., Dessen, O., Milgrom, E., 1995. Structure of the human luteinizing hormone-choriogonadotropin receptor gene: unusual promoter and 5' noncoding regions. Mol. Cell. Endocrinol. 87, 113-123.

Bazer, F.W., Thatcher, W., 1977. Theory of maternal recognition of pregnancy in swine based on estrogen controlled endocrine versus exocrine secretion of prostaglandin F $2 \alpha$ by the uterine endometrium. Prostaglandins 14, 397-401.

Blitek, A., Ziecik, A.J., 2005. Effect of $\mathrm{LH}$ on prostaglandyn $\mathrm{F}_{2 \alpha}$ and prostaglandin $\mathrm{E}_{2}$ secretion by cultured porcine endometrial cells. Reproduction 130, 105-112.

Bodek, G., Kowalczyk, A., Waclawik, A., Huhtaniemi, I., Ziecik, A.J., 2005a. Targeted ablation of prostate carcinoma cells through LH receptor using Hecate-CG $\beta$ conjugate: functional characteristic and molecular mechanism of cell death pathway. Exp. Biol. Med. $230,421-428$.

Bodek, G., Rahman, N.A., Zaleska, M., Soliymani, R., Lankinen, H., Hansel, W., Huhtaniemi, I., Ziecik, A.J., 2003. A novel approach of targeted ablation of mammary carcinoma cells through luteinizing hormone receptors using Hecate-CG $\beta$ conjugate. Breast Cancer Res. Treat. 79, 1-10. 
Bodek, G., Vierre, S., Rivero-Muller, A., Huhtaniemi, I., Ziecik, A.J., Rahman, N.A., 2005b. A novel targeted therapy of Leydig and granulosa cell tumors through the luteinizing hormone receptor using Hecate-chorionic gonadotropin $\beta$ conjugate in transgenic mice. Neoplasia 7, 497-508.

Boman, H.G., 1995. Peptide antibiotics and their role in innate immunity. Annu. Rev. Immunol. 13, 61-92.

Bonnamy, P.J., Benhaim, A., Leymarie, P., 1990. Estrous cycle-related changes of high affinity luteinizing hormone/human chorionic gonadotropin binding site in the rat uterus. Endocrinology 126, 1264-1269.

Christenson, L.K., Farley, D.B., Anderson, L.H., Ford, S.P., 1994. Luteal maintenance during early pregnancy in the pig: role for prostaglandin E2. Prostaglandins 47, 61-75.

Davis, D., Liu, X., Segaloff, D.L., 1995. Identification of the sites of N-linked glycosylation on the follicle-stimulating hormone (FSH) receptor and assessment of their role in FSH receptor function. Mol. Endocrinol. 9, 159-170.

Davis, D.L., Blair, R.M., 1993. Studies of uterine secretions and products of primary cultures of endometrial cell in pigs. J. Reprod. Fertil. Suppl. 48, 143-155.

Davis, J.S., Weakland, L.L., Farese R.V., West, R.V., 1987. Luteinizing hormone increases inositol trisphosphate and cytosolic free $\mathrm{CA}^{++}$in isolated bovine luteal cells. J. Biol. Chem. $262,8515-8521$.

Derecka, K., Pietila, E.M., Rajaniemi, H.J., Ziecik, A.J., 1995. Cycle dependent LH/hCG receptor gene expression in porcine non-gonadal reproductive tissues. J. Physiol. Pharmacol. $46,77-85$.

Dirnhofer, S., Berger, C., Hermann, M., Steiner, G., Madersbacher, S., Berger, P., 1998. Coexpression of gonadotropic hormones and their corresponding FSH- and LH/CG-receptors in the human prostate. Prostate 35, 212-220. 
Emons, G., Ortman, O., Pahwa, G.S., Hackenberg, R., Oberheuser, F., Schulz, K-D., 1992. Intracellular actions of gonadotropic and peptide hormones and the therapeutic value of GnRH-agonist in ovarian cancer. Acta Obstet. Gynecol. Scand. 71, 31-38.

Eta, E., Ambrus G., Rao, C.V., 1994. Direct regulation of human myometrial contractions by human chorionic-gonadotropin. J. Clin. Endocrionol. Metab. 79, 1582-1586.

Europe-Finner, G.N., Phaneuf, S., Watson, S.P., Lopez Bernal, A., 1993. Identification and expression of G-proteins in human myometrium: upregulation of $\mathrm{G} \alpha_{S}$ in pregnancy. Endocrinology 132, 2484-2490.

Ezimokhai, M., Osman, N., Agarwal, M., 2000 Human chorionic gonadotrophin is an endothelium-independent inhibitor of rat aortic smooth muscle contractility. Am. J. Hypertens. 13, 66-73.

Fields, M.J., Shemesh, M., 2004. Extragonadal luteinizing hormone receptors in the reproductive tract of domestic animals. Biol. Reprod. 71, 1412-1418.

Flowers, B., Ziecik, A.J., Caruolo, E.V., 1991. Effects of human chorionic gonadotropin on contractile activity of steroid-primed pig myometrium in vitro. J. Reprod. Fertil. 92, 425-432.

Ford, S.P., 1985. Maternal recognition of pregnancy in the ewe, cow and sow: vascular and immunological aspects. Theriogenology 23, 145-149.

Freidman, S., Gurevich, M., Shemesh, M., 1995. Bovine cyclic endometrium contains highaffinity luteinising hormone/human chorionic gonadotropin binding sites. Biol. Reprod. 52, 1020-1026.

Gadsby, J.E., Balapure, A.K., Britt, J.H., Fitz, T.A., 1990. Prostaglandin F2 alpha receptors on enzyme-dissociated pig luteal cells throughout the estrous cycle. Endocrinology 126, 787795.

Garverick, H.A., Polge, C., Flint, A.P.F., 1982. Oestradiol administration raises luteal LH receptor levels in intact and hysterectomized pigs. J. Reprod. Fertil. 66, 371-377. 
Gawronska, B., Leuschner, C., Enright, F.M., Hansel, W., 2002. Effect of a lytic peptide conjugated to $\beta$ hCG on ovarian Cancer: studies in vitro and in vivo. Gynecol. Oncol. 85, 4552.

Gawronska, B., Paukku, T., Huhtaniemi, I., Wasowicz, G., Ziecik, A.J., 1999. Oestrogendependent expression of $\mathrm{LH} / \mathrm{hCG}$ receptors in pig Fallopian tube and their role in relaxation of the oviduct. J. Reprod. Fertil. 115, 293-301.

Gawronska, B., Stepien, A., Ziecik, A.J., 2000. Effect of estradiol and progesterone on oviductal LHR and LH-dependent relaxation of porcine oviduct. Theriogenology 53, 659-672. Geng, Y., Tsai-Morris, C.H., Zhang, Y., Dufau M.L., 1999. The human luteinizing hormone gene promoter activation by $\mathrm{Sp} 1$ and $\mathrm{Sp} 3$ and inhibitory regulation. Biochem. Res. Commun. $263,366-371$.

Gregoraszczuk, E.L., Michas, N., 1999. Progesterone and estradiol secretion by porcine luteal cells is influenced by individual and combined treatment with prostaglandins E2 and F2 $\alpha$ throughout the estrous cycle. Prostaglandins Other Lipid Med. 57, 231-241.

Guthrie, H.D., Bolt, D.J., 1983. Changes in plasma estrogen, luteinizing hormone, follicle stimulating hormone and 13,14-dihydro-15-keto-prostaglandin F2 $\alpha$ during blockade of luteolysis in pigs after human chorionic gonadotropin treatment. J. Anim. Sci. 52, 993-1000.

Han, S.W., Lei., Z.M., Rao, C.V., 1996. Up-regulation of cyclooxygenase-2 gene expression by chorionic gonadotropin in mucosal cells from human fallopian tubes. Endocrinology 137, 2929-2937.

Hansel, W., Leuschner, C., Gawronska, B., Enright, F., 2001. Targeted destruction of prostate cancer cells and xenografts by lytic peptide- $\beta$ LH conjugates. Reprod. Biol. 1, 20-32.

Huhtaniemi, I.T., Esskola, V., Parakinen, P., Matikainen, T., Sprengel, R., 1992. The murine luteinizing hormone and follicle-stimulating hormone receptor genes: transcription initiation sites. Mol. Cell. Endocrinol. 88, 55-66. 
Jensen, J.D., Odell, W.D., 1988. Identification of $\mathrm{LH} / \mathrm{hCG}$ receptors in rabbit uterus. Proc. Soc. Exp. Biol. Med. 189, 28-30.

Kisielewska, J., Flint, A.P.F., Ziecik, A.J., 1996. Phospholipase C and adenylate cyclase signalling systems in the action of hCG on porcine myometrial smooth muscle cells. J. Endocrinol. 148, 175-180.

Kornyei, J.L., Lei, Z.M., Rao, C.V., 1993. Human myometrial smooth muscle cells are novel targets of direct regulation by human chorionic gonadotropin. Biol. Reprod. 49, 1149-1157.

Kotwica, G., Franczak, A., Okrasa, S., Kotwica J., 1999. Effect of an oxytocin antagonist on prostaglandin F2 $\alpha$ secretion and the course of luteolysis in sows. Acta Vet. Hung. 47, 249262.

Krzymowski, T., Stefańczyk-Krzymowska, S., 2002. Uterine blood supply as a main factor involved in the regulation of estrous cycle - new theory. Reprod. Biol. 2, 93-114.

Kurjak, A., Kupesic-Urek, S., Schulman, H., Zaiud, I., 1991. Transvaginal color flow Doppler in the assessment of ovarian, uterine blood flow in infertile women. Fertil. Steril. 56, 870-873. Lei, Z.M., Rao, C.V., Kornyei, J.L., Licht, P., Hiatt, E.S., 1993a. Novel expression of human chorionic gonadotropin/luteinizing hormone receptor gene in brain. Endocrinology 132, 22622270 .

Lei, Z.M., Rao, C.V., Lincoln, S.R., Ackermann, D.M., 1993b. Increased expression of human chorionic gonadotropin/human luteinizing hormone receptors in adenomyosis. J. Clin. Endocrinol. Metab. 76, 763-768.

Lei, Z.M., Toth, P., Rao, C.V., Pridham, D., 1993c. Novel coexpression of human chorionic gonadotropin $(\mathrm{hCG}) /$ human luteinizing hormone receptors and their ligand hCG in human fallopian tubes. J. Clin. Endocrinol. Metab. 77, 863-872. 
Leuschner, C., Enright, F.M., Gawronska, B., Hansel, W., 2003. Membrane disrupting lytic peptide conjugates destroy hormone dependent and independent breast cancer cells in vitro and in vivo. Breast Cancer Res. Treat. 78, 17-27.

Leuschner, C., Enright, F.M., Melrose, A., Hansel, W., 2001. Targeted destruction of androgen-sensitive and -insensitive prostate cancer cells and xenografts throught luteinizing hormone receptor. Prostate 46, 116-125.

Leuschner, C., Hansel, W., 2005. Targeting breast and prostate cancers through their hormone receptors. Biol. Reprod. 73, 860-865.

Lin, J., Lei, Z.M., Lojun, S., Rao, C.V., 1994. Increased expression of luteinizing hormone/human chorionic gonadotropin receptor gene in human endometrial carcinomas. J. Clin. Endocrinol. Metab. 79, 1483-1491.

Lin, J., Lojun, S., Lei, Z.M., Wu, W.X., Peiner, S.C., Rao, C.V., 1995. Lymphocytes from pregnant women express human chorionic gonadotropin/luteinizing hormone receptor gene. Mol. Cell. Endocrinol. 111, R13-R17.

Lin, P.C., Li, X., Lei, Z.M., Rao, C.V., 2003. Human cervix contains functional luteinizing hormone/human chorionic gonadotropin receptors. J. Clin. Endocrinol. Metab. 88, 3409-3414. Lojun, S., Bao, S., Lei, Z.M., Rao, C.V., 1997. Presence of functional luteinizing hormone/chorionic gonadotropin (hCG) receptors in human breast cell lines: implications supporting the premise that hCG protects women against breast cancer. Biol. Reprod. 57, 1202-1210.

Loosfelt, H., Misrahi, M., Atger, M., Salesse, R., Vu Hai-Luu Thi, M.T., Jolivet, A., Guiochon-Mantel, A., Sar, S., Jallal, B., Garnier, J., Milgrom, E., 1989. Cloning and sequencing of porcine LH-hCG receptor cDNA: variants lacking transmembrane domain. Science 45, 525-528.

Magrath, I.T., 1994. Targeted approaches to cancer therapy. Int. J. Cancer 56, 163-166. 
Marsh, J.M., 1975. The role of cyclic AMP in gonadal function. Adv. Cyclic Nucleotide Res. 6, 137-199.

Meduri, G., Charnaux, N., Loosfelt, H., Jolivet, A., Spyratos, F., Brailly, S., Milgrom, E., 1997. Luteinizing hormone/human chorionic gonadotropin receptors in breast cancer. Cancer Res. 57, 857-864.

Mizrachi, D., Shemesh, M., 1999. Expression of functional luteinizing hormone receptor and its messenger ribonucleic acid in bovine cervix: luteinizing hormone augmentation of intracellular cyclic AMP, phosphate inositol and cyclooxygenase. Mol. Cell. Endocrinol. 157, 191-200.

Moeljono, M.P.E., Thatcher, W.W., Bazer, F.W., Frank, M., Owens, L.J., Wilcox, C.J., 1977. A study of prostaglandin F2 $\alpha$ as the luteolysin in swine. II. Characterization and comparison of prostaglandin F, estrogens and progestin concentrations in utero-ovarian vein plasma of nonpregnant and pregnant gilts. Prostaglandins 14, 543-555.

Morbeck, D.E., Roche, P.C., Keutmann, H.T., McCormick, D.J., 1993. A receptor binding site identified in the region 81-95 of the beta-subunit of human luteinizing hormone (LH) and chorionic gonadotropin (hCG). Mol. Cell. Endocrinol. 97, 173-181.

Mukherjee, D., Manna, P.R., Bhattacharya, S., 1994. Functional relevance of luteinizing hormone receptor in mouse uterus. Europ. J. Endocrinol. 13, 103-108.

Pabon, J.E., Bird, J.S., Li, X., Huang, Z.H., Lei, Z.M., Sanfilippo, J.S., Yussman, M.A., Rao, C.V., 1996a. Human skin contains luteinizing hormone/chorionic gonadotropin receptors. J. Clin. Endocrinol. Metab. 81, 2738-2741.

Pabon, J.E., Li, X., Lei, Z.M., Sanfilippo, J.S., Yussman, M.A., Rao, C.V., 1996b. Novel presence of luteinizing hormone/chorionic gonadotropin receptors in human adrenal glands. J. Clin. Endocrinol. Metab. 81, 2397-2400. 
Parvizi, N., Elsaesser, F., Smidt, D., Ellendorf, F., 1976. Plasma luteinising hormone and progesterone in the adult female pig during the oestrous cycle, late pregnancy and lactation after ovariectomy and pentobarbitone treatment. J. Endocrinol. 69, 193-203.

Phillips, R.J., Bailey, J., Robson, S.C., Europe-Finner, G.N., 2002. The differential expression of the adenyl cyclase-stimulatory GTP-binding protein $\mathrm{G} \alpha \mathrm{S}$ in the human myometrium during pregnancy and labor involves transcriptional regulation by cyclic AMP and binding of phosphorylated nuclear proteins to multiple $\mathrm{GC}$ boxes within the promoter. J. Clin. Endocrinol. Metab. 87, 5675-5685.

Phillips, R.J., Tyson-Capper, A.J., Bailey, J., Robson, S.C., Europe-Finner, G.N., 2005. Regulation of expression of the chorionic gonadotropin/luteinizing hormone receptor gene in the human myometrium: involvement of specificity protein-1 (Sp1), Sp3, Sp4, Sp-like proteins, and histone deacetylases. J. Clin. Endocrinol. Metab. 90, 3479-3490.

Polejaeva, I.A., Chen, S.H., Vaught, T.D., Page, R.L., Mullins, J., Ball, S., Dai, Y., Boone, J., Walker, S., Ayares, D.L., Colman, A., Campbell, K.H., 2000. Cloned pigs produced by nuclear transfer from adult somatic cells. Nature 407, 86-90.

Rao, C.V., 1996. The beginning of a new area in reproductive biology and medicine: expression of low levels of functional luteinizing hormone/human chorionic gonadotropin receptors in nongonadal tissues. J. Physiol. Pharmacol. 47, 41-53.

Rao, C.V., 2001. An overview of the past, present, and future of nongonadal LH/hCG actions in reproductive biology and medicine. Semin. Reprod. Med. 19, 7-17.

Rao, C.V., Li X., Toth, P., Lei, Z.M., Cook, V.D., 1993. Novel expression of functional human chorionic gonadotropin/luteinizing hormone receptor gene in human umbilical cords. J. Clin. Endocrinol. Metab. 77, 1706-1714. 
Reshef, E., Lei, Z.M., Rao, Ch.V., Pridham, D.D., Chegini, N., Luborsky, J.L., 1990. The presence of gonadotropin receptors in nonpregnant human uterus, human placenta, fetal membranes, and decidua. J. Clin. Endocrinol. Metab. 70, 421-430.

Sawitzke, A.L., Odell, W., 1991. Uterine binding sites for LH/hCG can be modulated by hormonal status in rabbits and rats. Acta Endocrinol. (Copenh) 124, 322-330.

Shemesh, M., Freidman, S., Harel-Markowitz, E., Gurevich, M., 1994. Induction and regulation of the cyclooxygenase in the bovine endometrium. In: Zor, M. (ed.), Lipid Mediators in Health and Disease. Freund Publishing House Ltd., Tel-Aviv, pp.71-78.

Shemesh, M., Gurevich, M., Mizrachi D., Dombrowski L., Stram Y., Fields M.J., Shore L.S., 1997. Expression of functional luteinizing hormone (LH) receptor and its messenger ribonucleic acid in bovine uterine veins: LH induction of cyclooxygenase and augmentation of prostaglandin production in bovine uterine veins. Endocrinology 138, 4844-4851.

Singh, M., Zuo, J., Li, X., Ambrus, G., Lei, Z.M., Yussman, M.A., Sanfilippo, J.S., Rao, C.V., 1995. The decreased expression of functional human uterine leiomyomas. Biol. Reprod. 53, 899-904.

Slattery, M.M., Brennan, C., O’Leary, M.J., Morrison, J.J., 2001. Human chorionic gonadotropin inhibition of pregnant human myometrial contractility. Br. J. Obstet. Gyneacol. $108,704-708$.

Stepien, A., Derecka, K., Gawronska, B., Bodek, G., Zwierzchowski, L., Shemesh, M., Ziecik, A.J., 2000. LH/hCG receptors in the porcine uterus - a new evidence of their presence in the cervix. J. Physiol. Pharmacol. 51, 917-931.

Stepien, A., Shemesh, M., Ziecik, A.J., 1999. Luteinizing hormone receptor kinetic and LHinduced prostaglandin production throughout the estrous cycle in porcine endometrium. Reprod. Nutr. Develop. 39, 663-674.

Stepien, A., Ziecik, A.J., 2002. Second messenger systems in the action of LH and oxytocin 
on porcine endometrial cells in vitro. Theriogenology 57, 2217-2227.

Tao, Y-X. Bao, S., Ackermann, D.M., Lei, Z.M., Rao, C.V., 1997. Expression of luteinizing hormone/human chorionic gonadotropin receptor gene in benign prostatic hyperplasia and in prostate carcinoma in humans. Biol. Reprod. 56, 67-72.

Toth, P., Li, X., Rao, C.V., Lincoln, S.R., Sanfilippo, J.S., Spinnato, J.A. 2nd, Yussman, M.A., 1994. Expression of functional human chorionic gonadotropin/human luteinizing hormone receptor gene in human uterine arteries. J. Clin. Endocrinol. Metab. 79, 307-315.

Tsai-Morris, C.H., Buczko, E., Wang, W., Xie, X.Z., Dufau, M.L., 1991. Structural organization of rat luteinizing hormone (LH) receptor gene. J. Biol. Chem. 266, 11355-11359. Tsai-Morris, C.H., Geng, Y., Buczko, E., Dufau, M.L. 1995. Characterization of diverse functional elements in the upstream Sp1 domain of the rat luteinizing hormone receptor gene promoter. J. Biol. Chem. 270, 7487-7494.

Tsai-Morris, C.H., Xie, X.Z., Wang, W., Buczko, E., Dufau, M.L., 1993. Promoter and regulatory regions of the rat luteinizing hormone receptor gene. J. Biol. Chem. 268, 44474452.

Van Buren, G.A., Yang, D., Clark, K.E., 1992. Estrogen-induced uterine vasodilatation is antagonized by L-nitroarginine methyl ester, an inhibitor of nitric oxide synthesis. Am. J. Obstet. Gynaecol. 167, 828-833.

Van de Wiel, D.F.M., Erkens, J., Koops, W., Elene, V., van Landeghem, A.A.J., 1981. Periestrous and midluteal time courses of circulating LH, FSH, prolactin, estradiol-17 $\beta$ and progesterone in the domestic pigs. Biol. Reprod. 24, 223-233.

Wasowicz, G., Derecka, K., Stepien, A., Pelliniemi, L., Doboszynska, T., Gawronska, B., Ziecik, A.J., 1999. Evidence for the presence of luteinizing hormone/chorionic gonadotrophin receptors in the pig umbilical cord. J. Reprod. Fertil. 117, 1-9. 
Wasowicz, G., Ziecik, A.J., 2000. Influence of oestradiol and progesterone on the expression of LH/hCG receptors in the porcine broad ligament. Pol. J. Vet. Sci. 3, 119-130.

Weems, Y.S., Kim, L., Humphreys, V., Tsuda, V., Weems, C.W., 2003. Effect of luteinizing hormone (LH), pregnancy specific protein B (PSPB), arachidonic acid (AA) on ovine endometrium of the estrous cycle or secretion of prostaglandins E2 (PGE2) and F2alpha (PGF2alpha) progesterone in vitro. Prostaglandins Other Lipid Mediat. 71, 55-73.

Zaleska, M., Bodek, G., Jana, B., Hansel, W., Ziecik, A.J., 2003. Targeted destruction of normal and cancer cells through lutopin/choriogonadotropin receptors using Hecate-CG $\beta$ conjugate. Exp. Clin. Endocrinol. Diabet. 111, 146-153.

Zaleska, M., Waclawik, A., Bodek, G., Zezula-Szpyra, A., Li, X., Janowski, T., Hansel, W., Rahman, N.A., Ziecik, A.J., 2004. Growth repression in diethylstilbestrol/dimethylbenz[a]anthracene-induced rat mammary gland tumor using Hecate-CG $\beta$ conjugate. Exp. Biol. Med. 229, 335-344.

Zhang, Y., Dufau M.L., 2003. Dual mechanisms of regulation of transcription of luteinizing hormone receptor gene by nuclear orphan receptors and histone deacetylase. J. Steroid. Biochem. Mol. 85, 401-414.

Zheng, M., Shi, H., Segaloff, D.L., Van Voorhis, B.J., 2001. Expression and localization of luteinising hormone receptor in the female mouse reproductive tract. Biol. Reprod. 64, 179187.

Ziecik, A., Shaw, H.J., Flint, A.P.F., 1980. Luteal LH receptors during the estrous cycle and early pregnancy in the pig. J. Reprod. Fertil. 60, 129-13.

Ziecik, A.J., Bodek, G., Ciereszko, R., Stepien, A., Kotwica, G., 2001. Involvement of gonadotropins in induction of luteolysis in pigs. Reprod. Biol. 1, 33-50.

Ziecik, A.J., Derecka-Reszka, K., Rzucidlo, J.S., 1992a. Extragonadal gonadotropin receptors: their distribution and function. J. Physiol. Pharmacol. 43, 33-49 
Ziecik, A.J., Golba, G., Kisielewska, J., 1996. Effect of human chorionic gonadotropin on uterine blood flow in intact and ovariectomized gilts. Exp. Clin. Endocrinol. Diab. 104, 158163.

Ziecik, A.J., Jedlinska, M., Rzucidlo, J.S., 1992b. Effect of estradiol and progesterone on myometrial LH/hCG receptors in pig. Acta Endocrinol. (Copenh) 127, 185-188.

Ziecik, A.J., Ostrowska, G., Kisielewska, J., Zezula-Szpyra, A., 1995. Distribution and cycle phase dependency of gonadotropin receptors in musculature and blood vessels of the porcine broad ligament. Exp. Clin. Endocrinol. Diab. 103, 44-51.

Ziecik, A.J., Stanchev, P.D., Tilton, J.E., 1986. Evidence for the presence of luteinising hormone/human chronic gonadotropin - binding sites in the porcine uterus. Endocrinology $119,1159-116$.

Zuo, J., Lei, Z.M., Rao, C.V., 1994. Human myometrial chorionic gonadotropin/luteinizing hormone receptors in preterm and term delivers. J. Clin. Endocrinol. Metab. 79, 907-911. 


\section{Legends for figures}

Fig. 1. Human chorionic gonadotropin (hCG) inhibits amplitude of myometrial contractions in vitro (b) comparing to control (a) and prostaglandin $\mathrm{F}_{2 \alpha}$ stimulation (c) (Flowers et al., 1991). Reproduced with permission.

Fig. 2. Luteolysis in pigs. (A) Porcine CL is insensitive to exogenous $\mathrm{PGF}_{2 \alpha}$ until day 12 of the estrous cycle (insensitive period). Number of $\mathrm{PGF}_{2 \alpha}$ receptors increases dramatically on days 13 and remains high on days 14-17 (sensitive period; according to Gadsby et al., 1990). (B) Release of $\mathrm{PGF}_{2 \alpha}$ from endometrium is initiated and maintained by pleiotropic action of many factors including LH, oxytocin and tumor necrosis factor (TNF) $\alpha$. LHR - LH/hCG receptor; OTR - oxytocin receptor; TNFR - TNF $\alpha$ receptor; PR - progesterone receptor. LHR in corpus luteum and PR in the endometrium are down regulated after day 13 of the estrous cycle.

Fig. 3. The effect of $\mathrm{LH}$ on $\mathrm{PGF}_{2 \alpha}$ secretion by cultured porcine stromal (A) and luminal epithelial (B) cells obtained at days $10-12$ of the estrous cycle. LH $(0.1-100 \mathrm{ng} / \mathrm{ml})$ was added for $6 \mathrm{~h}$ in stromal and $12 \mathrm{~h}$ in luminal epithelial cells culture. Data are presented as mean \pm SEM. ${ }^{* *}, P<0.01 ; * * *, P<0.001$ when compared to control value (Blitek and Ziecik, 2005). Reproduced with permission. 
a

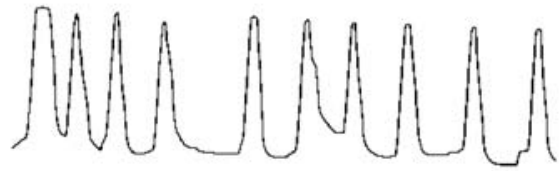

b

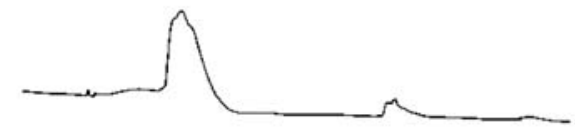

c

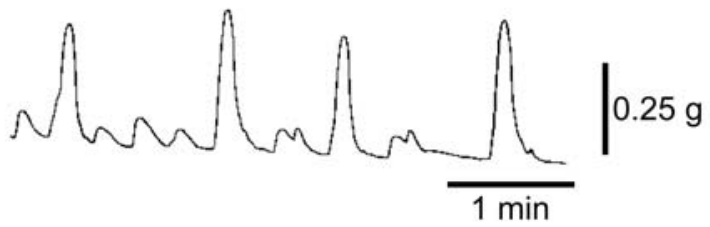


A

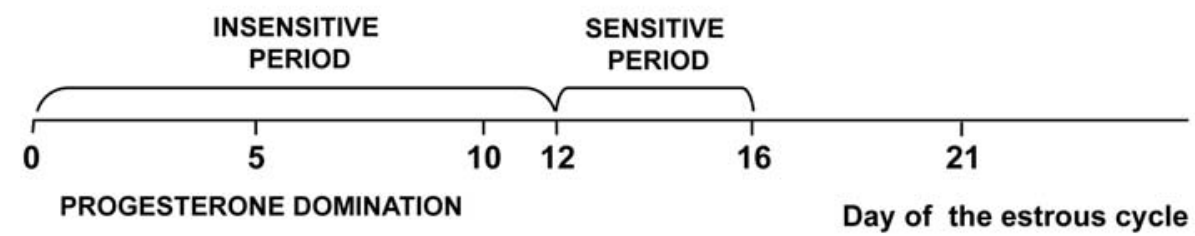

B

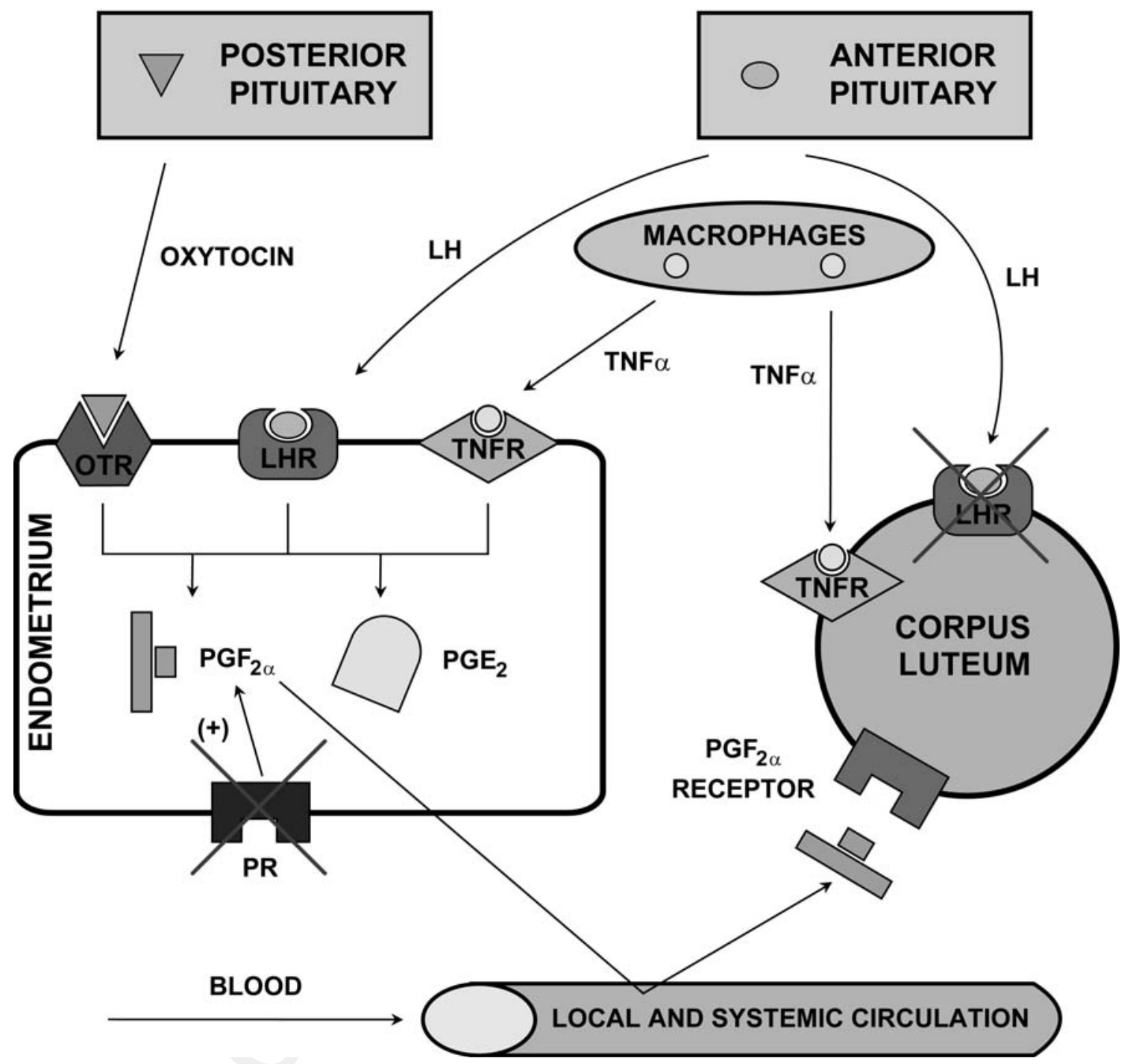




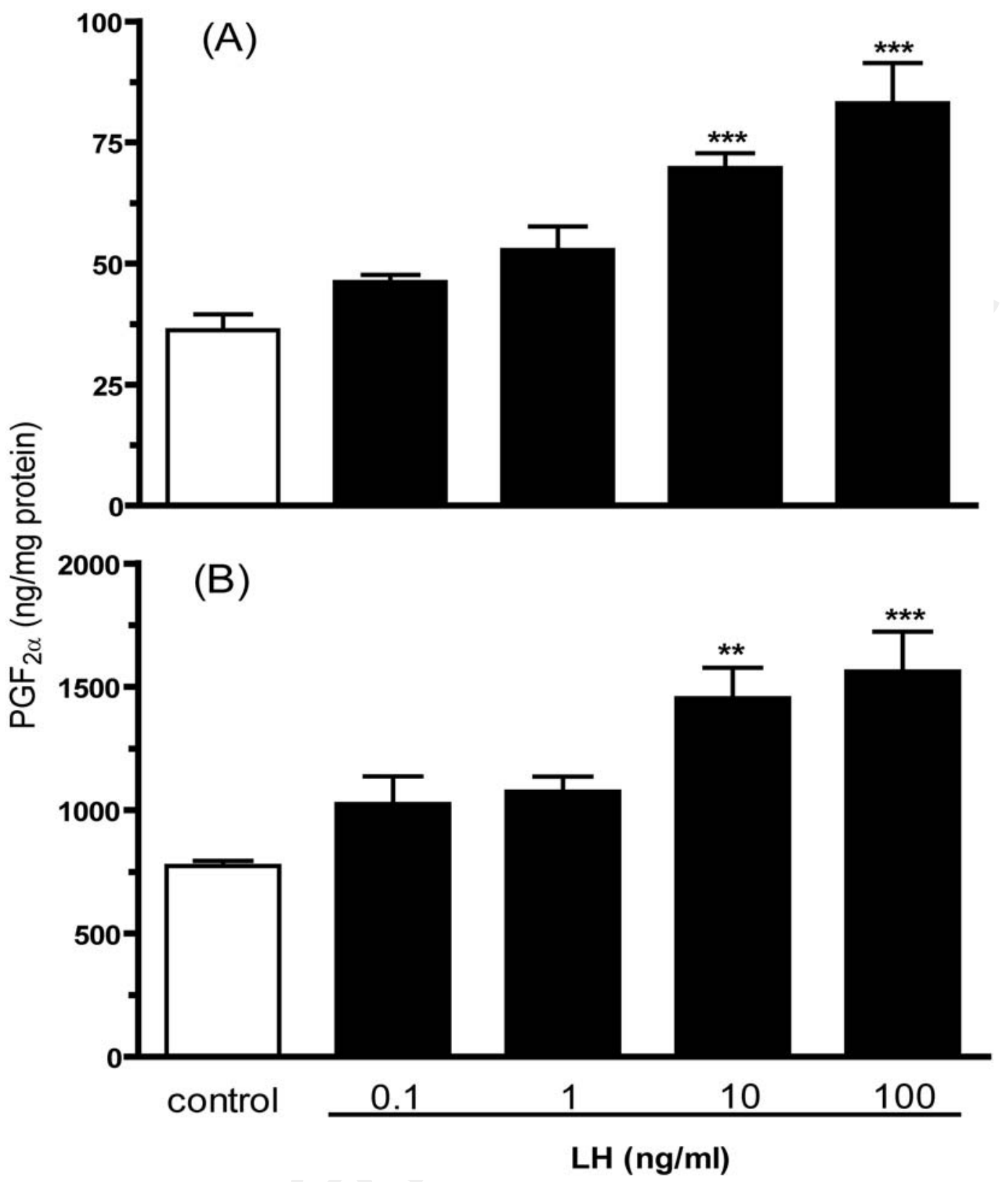

